\title{
Countermeasure Study on Synergetic Development of Agricultural E-commerce and Rural Logistics Network in Hubei Province
}

\author{
Ying Tan \\ School of Management, Wuhan Donghu College, Wuhan, Hubei , China \\ 85066405@qq.com
}

Keywords: Agricultural e-commerce, Rural logistics networks, Synergetic development, Countermeasure study.

\begin{abstract}
. based on the characteristics of local economy and relevant policies, this article analyzes the current situation of and the reasons for mutual restrictions between agricultural e-commerce and rural logistics in Hubei Province, and proposes the strategies for synergetic development between agricultural e-commerce and rural logistics in Hubei Province, which has provided theoretical basis and supports for developing agriculture e-commerce and establishing rural logistics networks throughout the country.
\end{abstract}

\section{Introduction}

As the agricultural e-commerce is now experiencing a rapid development in China, CPC Hubei Provincial Committee and the provincial government attaches great importance to the development of the rural logistics and the agricultural e-commerce and has introduced a series of policies and measures, which has ensured the remarkable development of the rural logistics system and the agricultural e-commerce in Hubei Province. Rural logistics plays an increasingly important role in farmers' life and production activities. The rural logistics system is gradually taking shape, covering four types of logistics including agricultural materials logistics, agriculture products logistics, rural consumer goods logistics and renewable resources logistics. In which, the agricultural materials and the rural consumer goods flow from urban areas to rural areas, while the agricultural products and the renewable resources flows oppositely. These four categories of subjects are the most important transaction products in the rural e-commerce. A complete e-commerce transaction involves "four flows”, i.e. information flow, business flow, capital flow and article flow (logistics). In which, information flow, business flow and capital flow can be realized with Internet technologies and methods, while the essence of logistics, the most particular flow, is the flow of physical objects, which cannot be realized through Internet. Therefore, to a large extent, the development of agricultural e-commerce depends on the synergetic degree between logistics and e-commerce.

\section{Analysis of the Current Mutual Restrictive Situation between Agriculture E-commerce and Rural Logistics}

The construction of rural logistics system in our province has reached a remarkable achievement, however, according to the researches on the development situation of agricultural e-commence in main agricultural products production area in the northwest and southwest of Hubei Province, , the mutual restriction between agricultural e-commerce and rural logistics is now severe.

\subsection{Discontinuous rural logistics links severely restricts the development of agricultural e-commerce.}

Surveys show that, on one hand, the coordination among farmer households, village- and townoriented agricultural products trading centers and the agricultural materials stores targeting villages and towns is unplanned, on the other hand, there are no large scale and systematic logistics nodes between village- and town- oriented agricultural products trading centers and the agricultural materials stores and the classified stores and dispatch centers in the city. These two factors result in the discontinuous rural logistics link. 
The northwest area of Hubei Province is famous for its tea and dried agricultural products. The on-line agricultural products transaction volume reached up to CNY 100,000,000 both in 2014 and in 2015. Agricultural product parcels, agricultural production material parcels and rural consumer goods parcels delivered from and to the county area exceed 150,000,000 pieces. However, according to the surveys conducted among the sellers, most sellers believe that the discontinuous rural logistics is the main factor that results in the high logistics cost and low logistics efficiency, which has severely restrict e-commence development. The sellers further expressed that the profits of the e-commerce are unsatisfactory due to the discontinuity of rural logistics, and if there is no improvement to the rural logistics networks, the development of agricultural e-commerce will be restricted with gloomy prospect. For example, in Baokang County in the northwest of Hubei Province, leading enterprises such as Aoli, Berry Town and Jingshanjin are making trials in agricultural product e-commerce, and the most challenging problems they are now faced with are discontinuous rural logistics links and high logistics costs.

In the southwest of Hubei Province where is famous for its fruits, vegetables, teas and dry products, and in the Jianghan plain where is famous for its eggs and aquatic products, although most enterprises involving agriculture have cooperated with a third platform or have established their own websites, but the websites and third party platforms are only used as a tool for product display and brand promotion. The on-line transaction volume is low, and the main sales come from the off-line local markets. The main cause is that the high logistics cost restricts the on-line transaction.

\subsection{Poor logistics infrastructure in rural area restricts the development of agricultural e-commerce}

The dual structure in urban and rural economy decides that, compared with urban area, logistics infrastructure in rural area is insufficient. Firstly, in rural area, the infrastructure facilities such as roads are in poor condition. In the recent 5 years, Hubei province increased its investment in constructing rural infrastructure facilities (roads), and the road and traffic conditions in rural area have been improved. Due to the long-term insufficient investment, lots of rural areas are short of funds, which results in poor road conditions and the roads left unrepair and without maintenance. Particularly, in some poverty-stricken area, the traffic condition is worse, which has seriously affect the efficiency of rural logistics. Secondly, the logistics transportation is also in poor condition. Currently, agricultural vehicles, modified vehicles, light and middle-duty trucks are used for distribution, and modern transportation facilities such as van, heavy duty truck and containers are rarely used, which have increased the logistics operation costs and weaken the market competitiveness. Finally, logistics technology in rural area is in a low level. (1) The packing technique and the packages used are in a low level. Hence, the agricultural products are easily contaminated and damage, which adversely impacts the sales of the agricultural products. (2) Large scale cold-chain logistics has not been formed. Normal temperature logistics and natural logistics are adopted for the agricultural products distribution, with poor refrigeration, frozen and preservation technologies, which results in agricultural product spoilage and loss.

\section{Countermeasure study on Synergetic Development between Agricultural E-commerce and}

\section{Rural Logistics Network in Hubei Province}

In consideration of the main problems regarding the synergic development of agricultural e-commerce and rural logistics networks in Hubei province, the author proposes corresponding suggestions and recommendations, so as to provide the decision basis for governments at all levels, agricultural competent departments and various agriculture operators.

3.1 Exerting the functions of the Supply and Marketing Cooperatives as a main channel, and improving rural logistics organizational system construction

According to the current development situation of the rural logistics in Hubei Province, the Supply and Marketing Cooperatives plays a leading role in modern rural distribution, and the function of the Supply and Marketing Cooperatives as a main channel in rural modern logistics system has been 
unveiled. In the 13th five-year plans for rural modern logistics system construction, the Supply and Marketing Cooperatives shall further exert its functions as a leading role.

\subsubsection{Establish and improve the rural logistics networks based on the Supply and Marketing}

Cooperatives (the main channel), and connecting "the last mile"

We have to thoroughly implement the spirit of the No. 1 Document issued by CPC Central Committee and CPC Hubei Committee in 2014, as well as the Opinions of the General Office of the State Council on Strengthening the Construction of Circulation System for Agricultural Product (No. 59 [2011]) and the Opinions of the State Council on Deepening the Circulation System Reform and Accelerating the Development of the Circulation Industry (No. 39 [2012] of the State Council), by integrating agriculture investments, government purchased services, and strengthening fiscal and tax policy supports, financial supports and projects supports, to implement the land policy for the public welfare wholesale market of agricultural products, to provide supports to the Supply and Marketing Cooperatives in organizing and Implanting the Supply and Marketing Cooperatives Systematic Agricultural Products Market Development Plan (2014-2020) and the 13th five-year plans for the rural modern logistics system construction. Strengthen the construction of the subordinate Comprehensive Service Committee at village-level, so as to have the rural logistics networks covered all administrative villages and connect the "last miles".

3.1.2 Giving full play to the traditional advantages and the operation and service networks advantage of the Supply and Marketing Cooperatives, and supporting functional diversification

Considering Supply and Marketing Cooperatives' role as the main channel, it is recommended that relevant departments shall assign tasks such as pilot project construction of public welfare wholesale market of agricultural products, farmer's market and vegetable market to the Supply and Marketing Cooperatives; provide necessary supports to the Supply and Marketing Cooperatives in enhancing construction of wholesale market of agricultural products, improving technologies such as factory pre-cooling, pre-selection and classification, process and delivering, cold-chain logistics, test and inspection and electronic settlements; provide support to the Supply and Marketing Cooperatives to participate in strategic collection and storage of important agriculture products including rice, oil, meet and spring and winter vegetables; provide supports to establish a batch of large scale agricultural product logistics enterprises of under the Supply and Marketing Cooperatives, and develop such enterprise to a modern logistics enterprise integrating processing, transport, storage, delivering, information, transaction and finance and other services.

\subsubsection{Building a new situation with the Supply and Marketing Cooperatives as the main hubs and} multiple logistics modes complement each other

Optimally configure urban and rural logistics networks resources, support the Supply and Marketing Cooperatives in circulation mode innovation, actively apply modern circulation methods and information technologies, develop multiple rural logistics modes (such as the Supply and Marketing Cooperatives system, coordination between agriculture and commerce, post logistics, transport logistics and third party logistics), build a new situation with the Supply and Marketing Cooperatives as the main hubs and multiple logistics modes (post logistics, transport logistics and third party logistics) complement each other, and carry out "existing capacity" integration and "expended capacity” configuration, so as to reconstruct the urban and rural logistics networks.

3.1.4 Strengthen the e-commerce terminals construction for the public organizations at all levels of the Supply and Marketing Cooperatives

Based on the traditional advantages and operation and services networks advantages of the Supply and Marketing Cooperatives, and make the most of the advantage of wide coverage, provide guidance to the Supply and Marketing Cooperatives to set up e-commerce terminals at the public organizations at all levels (such as the people's square and the comprehensive service committee at village level). Guide rural residents to form a new consumption habit, so as to promote on-line transaction of the agricultural materials and rural consumer goods, meanwhile, give full play to the functions of the on-line supplier of the public organizations of the Supply and Marketing Cooperatives, so that the 
agricultural products produced by farmers can enter to the circulation link directly and reduce transaction cost to a large extent.

\subsection{Strengthen the construction of rural logistics subjects and cultivate the new agricultural business entities}

All the nodes and elements of collaborative construction system of agricultural e-commerce and rural logistics network in Hubei are linked and interactive with each other. Only by depending upon the sound development of all elements in the system and giving full play to the role of "one point with multiple functions" , Hubei province can realize the considerable development of collaborative construction of agricultural e-commerce and rural logistics network. When compared with traditional peasant households, new agricultural business entities, like the leading enterprises in the agricultural industrialization and specialized farmer cooperatives, should not only play a basic role of logistics node, but more importantly, give full play to its main role of "one point with multiple functions" in the rural logistics.

Firstly, focus upon the regional advantageous agricultural product industry, cultivate the leading enterprises in agricultural industrialization with the proprietary intellectual property right and strong driving power, and cooperate with peasant households from villages and townships through multiple forms and in multiple fields and give full play to the hub role of "one point with multiple functions". The leading enterprise should make full use of its own resource and brand advantages, expand logistics distribution network, improve the scale and operating quality, strive to connect the manufacturers or large suppliers in the upstream and rural terminal market in the downstream and integrate such functions as purchase, distribution, wholesale, retail, scientific and technological service into a whole, in order to adapt to the new situation and task of "agriculture, rural area and farmer”. Secondly, develop the specialized farmers' cooperative vigorously, strengthen relevant service functions, such as sales, processing, transportation and storage of its agricultural products, and technology and information relating to the agricultural production operation by relying upon the universality and cohesion facing farmers and promote its development as a new type of agricultural business entity. Thirdly, develop the specialized cooperative organization for rural logistics, rely upon the specialized cooperative organization to link with functions in all aspects, such as the production, transportation, warehousing, processing and sales of agricultural products, perfect the logistics channel of agricultural products so as to reduce the logistics cost of agricultural products and improve economic benefit.

\subsection{Eye on boosting the rural information construction and promote the coordinated development of logistics and e-commerce}

The development of agricultural e-commerce is hindered by restricted access to Internet, high Internet costs and absence of a unified comprehensive information platform in the rural areas in Hubei due to the population density and construction difficulty. Embarking on accelerating the rural information construction will be of great practical significance for the coordinated development of logistics and e-commerce.

Firstly, build an information platform that integrates the rural logistics with market information. Use the Internet and specialized logistics information network as the base and support respectively, employ the EDI technology to structure the information platform that integrates the rural logistics with market information and speed up the information construction process for the enterprises engaged in the logistics, production and processing of agricultural products and supply of agricultural supplies and peasant households. Secondly, build a logistics information platform that involves multiple transportation modes. Construct a rural logistics information platform featured by multimodal transport, optimize the mode of road, water and air transportation and rationalize the allocation of rural logistics resources. Thirdly, build a comprehensive information platform for the rural logistics. Realize the circulation pattern of "buying and selling agricultural products on a national scale" for the agricultural product, improve the capability to collect and process goods information, attain the interactive timely data exchange and shorten the time required for the 
exchange of logistics information and operation by building the comprehensive information platform for the rural logistics. Fourthly, make available the value-added service for the logistics information. The value-added service for the rural logistics information mainly consists of customs declaration and clearance, quality management and control, simple assembly, special combination packaging, repackaging, recirculation service and insurance service, as well as provision of advanced information technology, such as the e-service and electronic data interchange (EDI) system for the processes like the freight forwarding, warehousing and distribution management, cargo tracking system, business process reengineering (ERP) and consulting service for the customer relation management (CRM).

\subsection{Strengthen the financial and fund support and shore up the development of terminal e-commerce platform for the agricultural products}

As a type of system engineering, the agricultural e-commerce is characterized by a considerable construction fund input at the initial stage and long profit-making cycle. Although relevant documents, like the Opinion on Accelerating the E-commerce Development, have been introduced and formulated by the provincial government and some local authorities, there is still a lack of detailed and strong specific measures. Hence, it is imperative to strengthen the financial and fund support for developing the agricultural e-commerce.

Firstly, recommend the provincial commerce department to allocate the special fund earmarked for developing the e-commerce of agricultural products in an attempt to support the construction of key e-commerce enterprises, platforms and bases for the agricultural products, and highlight the demonstration effect of key enterprises and platforms. Secondly, suggest the government to take the lead in supporting and guiding the e-commerce enterprises of agricultural products to attract the input of social fund widely, such as introducing the venture investment and issuing bond, raising funds through multiple means and broadening the financing channel. Thirdly, instruct the financial institution at the county (town) level to provide preference for the circulation field of agricultural products, improve the credit approval and issuance efficiency for small and medium e-commerce enterprises specialized in the agricultural products, provide the loan guarantee service for them through various forms actively and increase the support of e-commerce of the agricultural products[20]. Fourthly, strengthen the construction of e-commerce application terminal of convenience-for-people organizations at all levels in the supply and marketing cooperative system, rely upon the traditional advantages of supply and marketing cooperative and network advantages of operating service, and guide the supply and marketing cooperative to build the good and convenient e-commerce service terminal in the convenience-for-people organizations at all levels, such as the people's livelihood square and comprehensive service community at the village level.

\subsection{Strengthen the talents training and support and construct a high-quality team for the e-commerce logistics}

The short of management and information personnel associated with the logistics and e-commerce in the rural area of Hubei Province has restrained the rural logistics development significantly and caused it to fail to catch up with the development pace of agricultural e-commerce. Therefore, it is imperative to reinforce the training of logistics and e-commerce talents.

3.5.1 Increase the infrastructure input on the logistics and e-commerce education. The governmental departments, large logistics enterprises, e-commerce enterprises, professional colleges and social organizations should increase the input on the infrastructure construction intended for the rural logistics and e-commerce talents and particularly build the professional technical career institute for the oriented cultivation of rural logistics and e-commerce talents, establish and form a multi-layered professional team and lay a solid foundation for the development of rural logistics and agricultural e-commerce by cultivating talents.

3.5.2 Conduct the professional construction for the logistics management of agricultural products and agricultural e-commerce. Provide and expand specialties relating to the logistics management of agricultural products and agricultural e-commerce in the colleges and universities, allocate funds to 
support the research and innovation activities of colleges and universities and scientific research institution in the logistics field of agricultural products and cultivate a batch of high-quality management and professional technicians who have a good understanding of supply chain management and operation at all links of agricultural product logistics and adapt to the era development requirements about the agricultural product logistics for Hubei Province as soon as possible; give full play to advantages of the first Taobao Business School incorporated in Hubei and focus upon cultivating a batch of interdisciplinary talents who have got acquainted with the agricultural knowledge and operational management and mastered the information technology properly.

3.5.3 Perform the logistics and e-commerce talent training. Support the industry association to provide the professional training, establish a life-time vocational education system for the industries of agricultural product logistics and agricultural e-commerce, learn from internationally advanced experience and implement the professional certification system for employees in the modern logistics or e-commerce industry; hold and convene the training class in multiple forms to furnish the existing employees with professional knowledge training; relevant departments in charge of labor protection and agriculture should adjust the training direction of migrant workers in time and intensify efforts to supply the migrant workers with e-commerce skill training.

\section{Summary}

A sound rural logistics network is the profit-making source of the agricultural e-commerce, which can give an impetus to the high-speed development of rural logistics, promote the process of agricultural industrialization and form the new rural economic growth points. Hence, we should kick off the synergetic development of the agricultural e-commerce and rural logistics network without delay. Furthermore, greater efforts should be made to overcome difficulties, break through barriers and boost the synergetic development of the agricultural e-commerce and rural logistics network for Hubei Province that is rated as an important national production base of agricultural products due to its abundant agricultural product resources and high demand for agricultural supplies.

\section{Acknowledgements}

This paper is one of the stage-based achievements of 2015 scientific research project titled Research on Intensive Development Mode of Rural Logistics Network in Hubei that Boosts Agricultural e-commerce by Agricultural e-commerce Hubei Provincial Collaborative Innovation Center (Cultivation), Wuhan Donghu College.

This paper is one of the stage-based achievements of 2014 Hubei Provincial Social Science Foundation Project titled A Study on the Coordinated Development of Agricultural E-commerce and Rural Logistics Network in Hubei (Project No.: 2014051).

\section{References}

[1] Research Group for the Modern Agricultural Logistics Study Center, Report on the Rural Logistics Development in China (2013), China Cooperation Economy, Issue 9 in 2013:8-30.

[2] All China Federation of Supply and Marketing Cooperatives, Market Development Planning for the Agricultural Products of Hubei Provincial Supply and Marketing Cooperative System in 2014 (2014-2020).

[3] Joint Research Group from the Financial and Economy Office (Agricultural Office) and Commerce Department of Hubei Provincial Party Committee. Grasp Opportunities, Give Full Play to Advantages and Promote the Breakthrough Development of Agricultural Products E-commerce in Hubei. Decision-making Reference, Issue 47, September 22, 2014. 